\title{
Sliding mode control with observer for permanent magnet synchronous machine drives
}

\author{
Muhammad Haziq Nashren Razali ${ }^{1}$, Jurifa Mat Lazi ${ }^{1}$, Zulkifilie Ibrahim ${ }^{1}$, Md Hairul Nizam Talib ${ }^{1}$, \\ Fizatul Aini Patakor ${ }^{2}$ \\ ${ }^{1}$ Department of Industrial Power, Faculty of Electrical Engineering, Universiti Teknikal Malaysia Melaka, Melaka, Malaysia \\ ${ }^{2}$ Department of Electrical, Politeknik Merlimau Melaka (PMM), Melaka, Malaysia
}

\begin{tabular}{l} 
Article Info \\
\hline Article history: \\
Received Jun 22, 2021 \\
Revised Nov 24, 2021 \\
Accepted Dec 2, 2021 \\
\hline Keywords: \\
Disturbance observer \\
Field-oriented control \\
Permanent magnet synchronous \\
motor \\
Sliding mode control
\end{tabular}

\begin{abstract}
This paper aims to develop the sliding mode control (SMC) scheme in sensorless permanent magnet synchronous machine (PMSM) drives to replace conventional proportional integral (PI) speed control. The SMC is formulated based on the integral sliding surface of the speed error. And the error is corrected based on the concept of Lyapunov stability. The SMC is designed with the load torque observer so that the disturbance can be estimated as feedback to the controller. The vector control technique which is also known as field-oriented control (FOC) is also used to split the stator current into the magnetic field generating part which is the direct axis and the torque generating part which is the quadrature axis. This can be done by using Park and Clarke transformations. The performance of the proposed SMC is tested under changes in load-torque and without load for different speed commands. The results prove that the SMC produces robust performances under variations of speeds and load disturbances. The effectiveness of the proposed method is verified and simulated by using MATLAB/SIMULINK software.
\end{abstract}

This is an open access article under the CC BY-SA license.

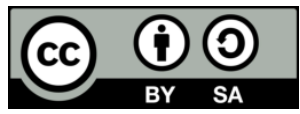

\section{Corresponding Author:}

Jurifa Mat Lazi

Department of Industrial Power, Faculty of Electrical Engineering, Universiti Teknikal Malaysia Melaka

Hang Tuah Jaya, 76100 Durian Tunggal, Melaka, Malaysia

Email: jurifa@utem.edu.my

\section{INTRODUCTION}

In recent years, sensorless machine drive has been widely used in servo applications because of its high reliability, low cost and also its smaller size. Permanent magnet synchronous machine (PMSM) is a popular machine drive that has advantages such as higher efficiency due to the absence of the magnetizing current, lower losses and lowers current for no-load conditions. PMSM also uses decoupling control, which makes it less sensitive to the speed and load variations of the motor [1]-[3]. PMSM is usually used for application which requires higher performance and higher efficiency for machine drives. High-performance machine control is classified as smooth running for all ranges of speed with full torque control at zero speed operation. To achieve that type of control, the field-oriented control (FOC) is the most commonly used control strategy of PMSM and it is preferable by the industry. However, this type of control technique is sensitive to parameters variation and load disturbances.

To solve these problems, many nonlinear control strategies have been implemented such as sensorless drives [4]-[6], model predictive control (MPC) [7], [8], backstepping control [9], [10], Kalman filtering [11], [12], and sliding mode control [13]-[15]. The FOC technique is also called vector control. The main objective of the field oriented control method is to produce the part of generating the magnetic field and the part of generating torque from the stator current part. Both components can be controlled separately after the transformation. 
Subsequently, the structure of the machine control is almost similar to separately excited DC motor, which makes the control of a permanent synchronous machine (PSM) drives easier.

Previously, the control method using the sliding mode control (SMC) has been the focus of studies and researches for machine drive systems. This is due to many features which are fast dynamic response, robustness to parameter variation and also simplicity of design and implementation. In SMC strategy, the drive's response is forced to follow along predefined trajectory by switching the signal in a phase plane. Other than that, the strategy of SMC can be divided into different strategies such as using state observer [16]-[18] and disturbance observer [19]. Through these strategies, the observer is introduced to estimate the disturbance so that it can be compensated based on the observed value. This topology is expected to reduce the chattering system and giving a faster speed response and reduce the ripple during the loaded condition. Other researchers also use sliding surface [20], [21], and terminal SMC [22]-[24]. While another strategy is using control law [25]-[27], which introduce the non-linear term by choosing the appropriate law so that it can reduce the chattering problem and reduce the convergence rate. Other than that, few researchers are trying to use fuzzy logic control with SMC [28], [29] and applying optimization for SMC [30] to control the machine drives. This current research chooses the disturbance observer based on the load torque estimation so that it can be controlled by the sliding mode controller.

This paper presents the performance of the SMC with the load torque observer. It is arranged such in part 1 is about the introduction of SMC, part 2 presents the model and derivation of the proposed method which consists of PMSM modelling, sliding mode control and the torque load observer. Part 3 shows the simulation results and the analysis of the results with and without the SMC during parameter variations and load disturbances. The validity of the proposed method is verified using MATLAB/SIMULINK software. Lastly, the discussion is included is in part 4.

\section{MATHEMATICAL MODEL OF PMSM}

An equivalent circuit of PMSM which being used to develop the dynamic equations in the $d-q$ axis [1] is shown in Figure 1. The quadrature and direct voltage equations $\left(V_{q}\right.$ and $\left.V_{d}\right)$ for the stator flux linkage $(\lambda)$ along the $d-q$ axis are presented in (1) and (2). While, $i_{d}$ and $i_{q}$ are the currents in the $q$ - $d$ axis and $\rho$ is the differential factor. The $q$ - $d$ axis stator flux linkage based on rotor reference frames are then shown in (3) and (4).

$$
\begin{aligned}
& V_{q}=R_{q} i_{q}+\omega_{r} \lambda_{d}+\rho \lambda_{q} \\
& V_{d}=R_{d} i_{d}-\omega_{r} \lambda_{q}+\rho \lambda_{d} \\
& \lambda_{q}=L_{q} i_{q} \\
& \lambda_{d}=L_{d} i_{d}+\lambda_{f}
\end{aligned}
$$

Where $L_{d}$ and $L_{q}$ are the inductances for the $d$ - $q$ axis. Substituting (3) and (4) into (1) and (2), rearrange the equations in matrix form, the voltages equations will be written as (5),

$$
\left(\begin{array}{c}
V_{q} \\
V_{d}
\end{array}\right)=\left(\begin{array}{cc}
R_{S}+\rho L_{q} & \omega_{r} L_{d} \\
-\omega_{r} L_{q} & R_{S}+\rho L_{d}
\end{array}\right)\left(\begin{array}{l}
i_{q} \\
i_{d}
\end{array}\right)+\left(\begin{array}{c}
\omega_{r} \lambda_{f} \\
\rho \lambda_{f}
\end{array}\right)
$$

where $R_{s}$ is the stator resistance and $\lambda_{f}$ is the field flux. Then, with $P$ is the pole pair, the electromagnetic torque $T_{e}$, can be formularized as (6).

$$
T_{e}=\frac{3}{2}\left(\frac{P}{2}\right)\left(\lambda_{d} i_{q}-\lambda_{q} i_{d}\right)
$$

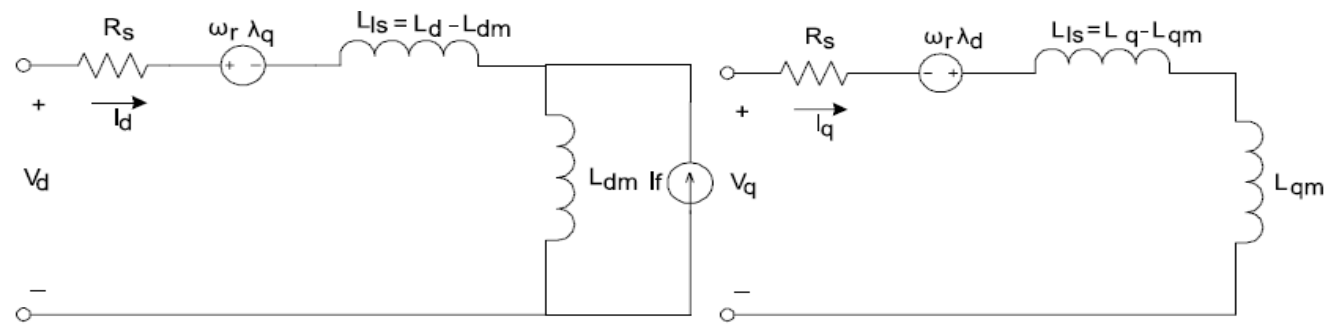

Figure 1. Equivalent circuit for permanent magnet synchronous machine (PMSM) 


\subsection{Field oriented control (FOC)}

A FOC or vector control (VC) can be developed from the dynamic model of the PMSM based on Figure 2. Using the Park's transformation, the 3-phase currents, $i_{a}, i_{b}$ and $i_{c}$ in the stator windings can be transformed into the rotor reference frame's currents. Considering the three-phase line current $\left(i_{a}, i_{b}, i_{c}\right)$ as input:

$$
\begin{aligned}
& i_{a}=I_{s} \sin \left(\omega_{r} t+\alpha\right) \\
& i_{b}=I_{s} \sin \left(\omega_{r} t+\alpha-\frac{2 \pi}{3}\right) \\
& i_{c}=I_{s} \sin \left(\omega_{r} t+\alpha+\frac{2 \pi}{3}\right)
\end{aligned}
$$

Transform (7) to (9) into the matrix form,

$$
\left[\begin{array}{l}
i_{a} \\
i_{b} \\
i_{c}
\end{array}\right]=\left[\begin{array}{c}
\cos \left(\omega_{r} t+\alpha\right) \\
\cos \left(\omega_{r} t+\alpha-\frac{2 \pi}{3}\right) \\
\cos \left(\omega_{r} t+\alpha+\frac{2 \pi}{3}\right)
\end{array}\right]\left[I_{s}\right]
$$

" $\alpha$ " is the different angle between stator and rotor currents in phasor and $\omega_{r}$ is the electrical rotor speed. The $d-q$ currents $\left(i_{q}\right.$ and $\left.i_{d}\right)$ are constant in the rotor reference frame due to fix " $\alpha$ " for a given load torque. They could be written as (11),

$$
\left[\begin{array}{l}
i_{q} \\
i_{d}
\end{array}\right]=I_{s}\left[\begin{array}{c}
\sin \alpha \\
\cos \alpha
\end{array}\right]
$$

the electromagnetic torque $T_{e}$ equation is presented as (12),

$$
T_{e}=\frac{3}{2} \frac{P}{2}\left[\frac{1}{2}\left(L_{d}-L_{q}\right) I_{s}^{2} \sin 2 \alpha+\lambda_{f} I_{s} \sin \alpha\right]
$$

which $L_{d}$ and $L_{q}$ are the inductances for the $d-q$ axis. And the electrical speed, $\omega_{e}$ is formularized as (13),

$$
\dot{\omega}_{e}=\frac{P}{J}\left(T_{\mathrm{e}}-T_{L}-\frac{B}{P} \omega_{\mathrm{e}}\right)
$$



Figure 2. Block diagram for PMSM drive with sliding mode control (SMC)

\subsection{Sliding mode control (SMC)}

In this research, the SMC will be used to investigate its usefulness as a tracking controller for the speed of a PMSM. The controller aims to follow the reference speed $\omega_{\text {ref }}$ with the angular speed of the rotor $\omega_{e}$ (the acceleration and position are not considered). The error signal " $e$ ", between the reference speed and actual speeds is determined as $e=\omega_{\text {ref }}-\omega_{e}$, which will represent the sliding surface "s". Since the speed control loop is based on a first-order system, the derivation of the SMC design is based on the concept of Lyapunov stability. With the Lyapunov candidate function, "V" as written [24], 


$$
\mathrm{V}=\frac{1}{2} s^{2}
$$

the equation must be in positive definite. The derivation is written as (14),

$$
\dot{V}=s \dot{S}<0 \forall s
$$

which must be in negative definite. Because it has the sliding surface " $s$ " in the form of,

$$
s=\omega \mathrm{ref}-\omega \mathrm{e}, \text { Then } \dot{s}=\dot{\omega} \mathrm{ref}-\dot{\omega} \mathrm{e}
$$

now substitute for $\dot{\omega}_{\mathrm{e}}$ and get,

$$
\dot{S}=\dot{\omega r e f}-\frac{P}{J}\left[T_{\mathrm{e}}-\frac{B}{P} \omega_{\mathrm{e}}-T_{L}\right]
$$

substituting $T_{\mathrm{e}}$, then obtain,

$$
\dot{s}=\dot{\omega} \mathrm{ref}-\frac{3 P^{2} \emptyset_{m}}{2 J} I_{q}+\frac{B}{J} \omega_{\mathrm{e}}+\frac{P}{J} T_{L}
$$

now, need to force $\dot{s}$ to zero. At no-load condition $\left(T_{L}=0\right)$, (15) becomes,

$$
\dot{\omega} \mathrm{ref}-\frac{3 P^{2} \emptyset_{m}}{2 J} I_{q}+\frac{B}{J} \omega_{\mathrm{e}}=0
$$

where $\theta_{m}$ is the magnitude of flux linkage by the permanent magnet of phases, $\mathrm{B}$ and $\mathbf{J}$ are the friction coefficient and moment of inertia of the motor respectively. Then, the equation can solve for $I_{q}$,

$$
I_{q}=\frac{2 J}{3 P^{2} \emptyset_{m}}\left[\dot{\omega}_{\text {ref }}+\frac{B}{J} \omega_{\mathrm{e}}\right]
$$

The (16) is used to make sure that the trajectory system will lead to the sliding surface " $s$ ", $\dot{s}=0 \rightarrow$ $s=$ constant. And also to make sure that results $\dot{V}=s \dot{s}=0$. However, the trajectory of the sliding surface is not enough for the state of stability, as it requires the system to maintain on the surface $\mathrm{s}=0$, where the error signal " $e$ " is equal to zero, to achieve $\dot{V}<0$. Other than that, in (16) requires another term to make sure that the trajectory is still on the sliding surface $\forall$ "s". This term is involved by a switching function, such as the sign function, which is presented by,

$$
\operatorname{sgn}(s)=\left\{\begin{array}{cc}
1 & s>0 \\
0 & s=0 \\
-1 & s<0
\end{array}\right.
$$

therefore, the reference q-axis current $I_{q}{ }^{*}$ is determined with the following scheme,

$$
I_{q}^{*}=\frac{2 J}{3 P^{2} \emptyset_{m}}\left[\dot{\omega}_{r e f}+\frac{B}{J} \omega_{\mathrm{e}}\right]+k_{c} \operatorname{sgn}(s)
$$

which the constant $k_{c}$ is again to satisfy the stability. Then, substitute $I_{q}{ }^{*}$ into (15),

$$
\dot{s}=-K_{a} \operatorname{sgn}(s)
$$

where $K_{a}=\left(\frac{3 P^{2} \emptyset_{m}}{2 J}\right) k_{c}$. Hence, the stability in the no-load condition, as in (13) becomes $\dot{V}=$ $s\left(-K_{a} \operatorname{sgn}(s)\right)$. Then,

$$
\dot{V}=-K_{a}|s|
$$

providing $K_{a}>0$ in (18), it guarantees that $\dot{V}<0$ or negative definite. So, the stability condition is satisfied $\forall s$.

\subsection{Observer}

An observer is formularized based on the error signal $\left(\hat{e}=\omega_{\mathrm{e}}-\widehat{\omega}_{\mathrm{e}}\right)$. It will be used in the feedback into the system back to increase the performance of the drive, in particular, to compensate for the disturbances. 
The observer is to calculate the estimated torque-load, " $T_{L}$ " and to compensate for other system variations that make the system robust in terms of uncertainties in modelling the nonlinear functions in the model. The observer output signal $\widehat{T}_{L}$ will be fed-forward to the controller. The estimated torque-load $\widehat{T}_{L}$ compensates the steady-state error between the actual electrical speed $\omega_{e}$ and the estimated electrical speed $\widehat{\omega}_{e}$. Figure 3 depicts the structure of the proposed SMC observer.

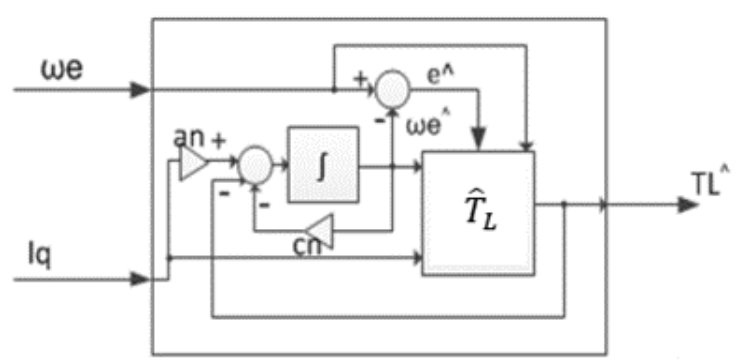

Figure 3. The structure of the SMC observer

Then, the proposed SMC is derived as derived in (17), and then to be substituted in (13). Therefore, an observer is proposed to estimate the torque-load based on the $d-q$ axis model, so that it can reduce he chattering phenomenon and improve the speed response of the drive. The estimated load torque is presented in (20),

$$
\widehat{T}_{L}=\frac{J}{P}\left(-\dot{\omega}_{e}+\frac{3 P^{2} \emptyset_{m}}{2 J} I_{q}-\frac{B}{J} \widehat{\omega}_{\mathrm{e}}\right)-k_{o} \hat{e}
$$

\section{RESULTS}

The Simulation results of the PMSM drives using the proposed SMC scheme are presented in this part. Figure 4 shows the overall Simulink model of PMSM with SMC using MATLAB/SIMULINK. To show the effectiveness of the proposed control system, two tests were conducted which are performed with a variety of speeds under no-load conditions and performance under load variation. The system also is compared with the proportional integral (PI) controller which represents the system "without SMC". The specification of the PMSM is tabulated in Table 1.

Table 1. Motor parameters

\begin{tabular}{ll}
\hline \multicolumn{1}{c}{ Parameter } & \multicolumn{1}{c}{ Value } \\
\hline Stator phase resistance $\left(R_{s}\right)$ & $0.2 \Omega$ \\
Inductance $\left(L_{d}\right)$ & $8.5 \mathrm{e}-3$ \\
Inductance $\left(L_{q}\right)$ & $8.5 \mathrm{e}-3$ \\
Magnetic flux linkage $\left(\emptyset_{m}\right)$ & $0.175 \mathrm{~Wb}$ \\
Inertia $(\mathrm{J})$ & $0.0027 \mathrm{~kg} \cdot \mathrm{m}^{2}$ \\
Viscous damping $(\mathrm{B})$ & 0.0004924 N.m.s \\
Pole pairs & 4 \\
Rated torque $\left(\mathrm{T}_{\text {rated }}\right)$ & $8 \mathrm{Nm}$ \\
Rated speed $\left(\omega_{\text {rated }}\right)$ & $1000 \mathrm{rpm}$ \\
\hline
\end{tabular}

The system is tested under three-speed operations which are at rated speed 1,000 rpm, half of the rated speed $500 \mathrm{rpm}$ and low speed, $300 \mathrm{rpm}$. Figure 5(a) shows the speed response at rated speed, 1,000 rpm with no load conditions. When the PMSM with SMC is tested running at rated 1,000 rpm, the speed response during transient has overshoot $1.5 \mathrm{rpm}$ and the system reached steady state at $0.15 \mathrm{~s}$. Meanwhile, in Figure 5(b), for speed $500 \mathrm{rpm}$, the system has an overshoot of $1.2 \mathrm{rpm}$ and a steady-state at $0.08 \mathrm{~s}$. Lastly, at speed $300 \mathrm{rpm}$, in Figure 5(c), the system has an overshoot of about $0.8 \mathrm{rpm}$ and reach steady-state at the fastest time $0.046 \mathrm{~s}$. Its shows that the proposed controller can response well under variation of speed condition without large overshoot. Since SMC is the robust controller, the motor was run at all test speeds under load conditions which are at $\mathrm{TL}=8 \mathrm{Nm}$, at half of rated load $\mathrm{TL}=4 \mathrm{Nm}$ and also at $\mathrm{TL}=2.4 \mathrm{Nm}$. The objective of the test is to verify the robustness of the SMC under a variety of loads. Figures 6(a), (b), and (c) show the system speed response when the load is applied at $0.5 \mathrm{~s}$ at three different speed commands. When the motor is operated at a rated speed of 1,000 rpm, the system has undershot $50 \mathrm{rpm}$ and recovered within $0.018 \mathrm{~s}$ for a full rated load $8 \mathrm{Nm}$ applied during steady state. 




Figure 4. Simulink model of PMSM with SMC

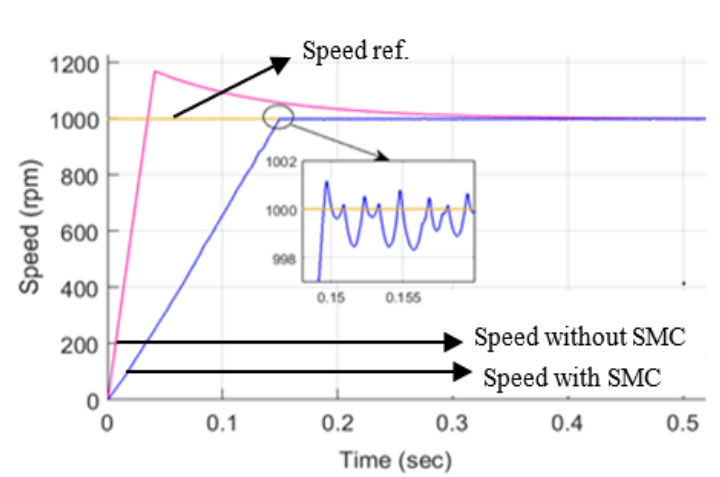

(a)

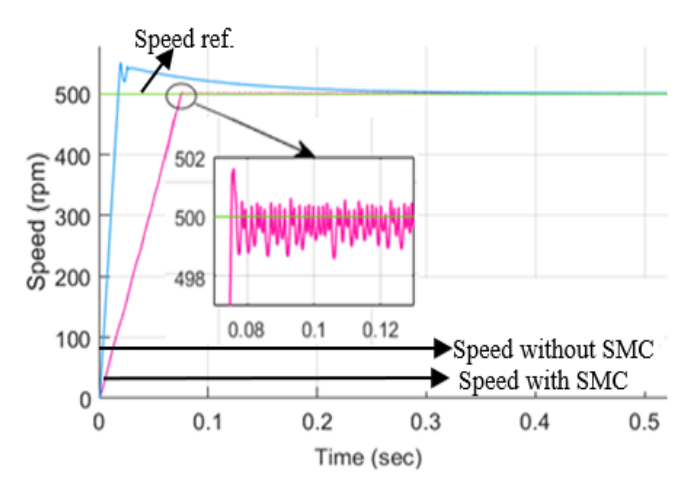

(b)

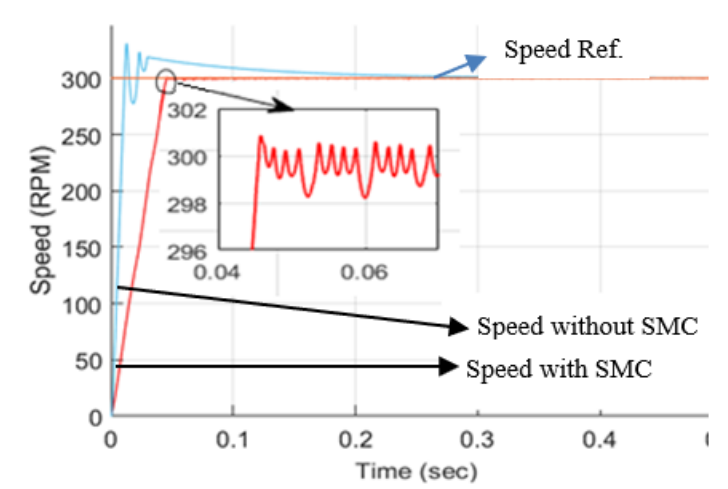

(c)

Figure 5. Speed performance when $\mathrm{TL}=0$ at a different speed at (a) at rated $1000 \mathrm{rpm}$, (b) at $500 \mathrm{rpm}$, and (c) at $300 \mathrm{rpm}$

Meanwhile, the undershoot and recovery time when a half rated load $4 \mathrm{Nm}$ is given are $16 \mathrm{rpm}$ and $0.005 \mathrm{~s}$ respectively. Then, load $2.4 \mathrm{Nm}$ is applied gives undershoot $5 \mathrm{rpm}$ with $0.004 \mathrm{~s}$ recovery time. Besides, the motor-operated at half rated speed $500 \mathrm{rpm}$. During load, $8 \mathrm{Nm}$ has applied the system has the undershoot $68.75 \mathrm{rpm}$ with settling time $0.02 \mathrm{~s}$. At $4 \mathrm{Nm}$ load disturbance, the system undergoes $21.8 \mathrm{rpm}$ of undershoot within $0.011 \mathrm{~s}$ recovery time. While the undershoot is $12.5 \mathrm{rpm}$ and recovered in $0.009 \mathrm{~s}$ when the $2.4 \mathrm{Nm}$ load is given to the system. Lastly, the motor is running at a speed of $300 \mathrm{rpm}$ with the variation of load. At load $8 \mathrm{Nm}$, the system shows the largest undershoot about $90.909 \mathrm{rpm}$ and settled down in $0.028 \mathrm{~s}$. At applied load $4 \mathrm{Nm}$, the undershoot is about $31.818 \mathrm{rpm}$ with a recovery time of $0.027 \mathrm{~s}$ to get a steady-state. Meanwhile, the undershoot and recovery time for $2.4 \mathrm{Nm}$ applied load are $13.636 \mathrm{rpm}$ and $0.019 \mathrm{~s}$ respectively. 


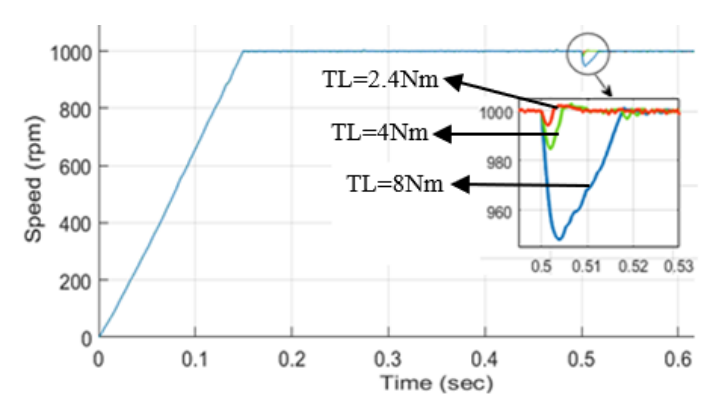

(a)

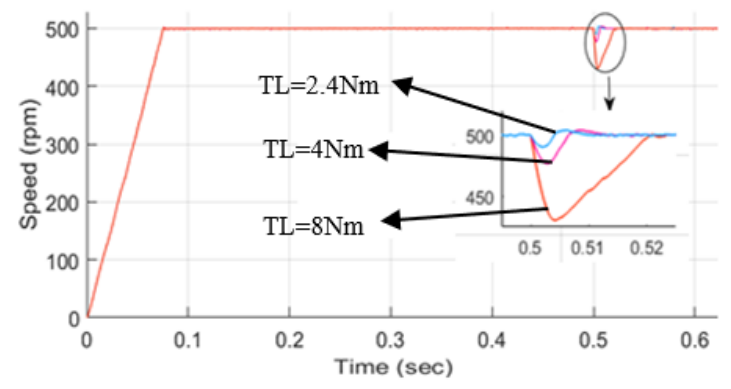

(b)

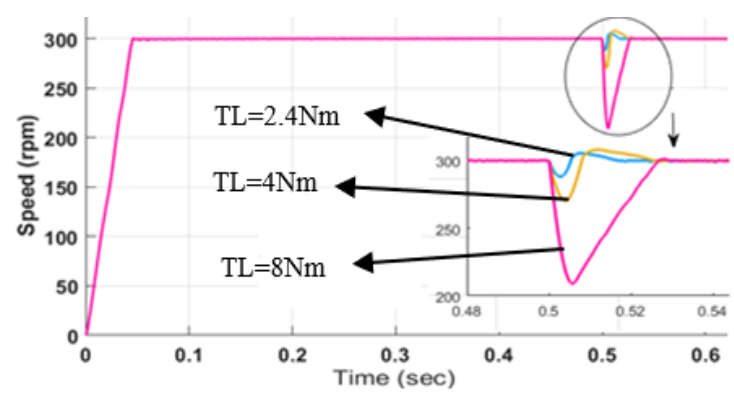

(c)

Figure 6. Speed performance when torque load is applied at a different speed at (a) at rated $1000 \mathrm{rpm}$, (b) at $500 \mathrm{rpm}$, and (c) at $300 \mathrm{rpm}$

\section{CONCLUSION}

A SMC with an observer for PMSM has been presented in this paper. The indirect field orientation control is used to ensure the control torque and magnetizing flux separately. Based on the results obtained, it can be concluded that the proposed sliding mode control can provide robust performance for speed and load variation. These conditions show that SMC maintains robustness to the load disturbances. For recommendation, there are several implementation need to be done for further research which are, hardware implementation of the proposed control scheme and selective adjustable functional gain parameters in the functional gain SMC to work with a different PMSM with its parameters.

\section{ACKNOWLEDGEMENTS}

The author would like to acknowledge the "Centre of Robotic \& Industrial Automation" (CERIA), "Centre of Research and Innovation Management" (CRIM), Universiti Teknikal Malaysia Melaka (UTeM) and Ministry of Higher Education Malaysia (MOHE) for supporting this project.

\section{REFERENCES}

[1] Z. Haigang, Q. Weiguo, W. Yanxiang, G. Shihong, and Y. Yuan, "Modeling and simulation of the permanent-magnet synchronous motor drive," 2011 International Conference on Uncertainty Reasoning and Knowledge Engineering, 2011, pp. 256-260, doi: 10.1109/URKE.2011.6007882.

[2] S. Konaka, Y. Inoue, S. Morimoto, and M. Sanada, "Comparative study of control characteristics in ultra-high-speed PMSM drives," 2014 IEEE 5th International Symposium on Sensorless Control for Electrical Drives, 2014, pp. 1-6, doi: 10.1109/SLED.2014.6844966.

[3] M. Saleque, A. M. A. Khan, S. H. Khan, E. Islam, and M. N. Chowdhury, "Variable speed PMSM drive with DC link voltage controller for light weight electric vehicle," 2017 International Conference on Electrical, Computer and Communication Engineering (ECCE), 2017, pp. 145-151, doi: 10.1109/ECACE.2017.7912896.

[4] A. Accetta, M. Cirrincione, M. Pucci, and G. Vitale, "Sensorless Control of PMSM Fractional Horsepower Drives by Signal Injection and Neural Adaptive-Band Filtering," in IEEE Transactions on Industrial Electronics, vol. 59, no. 3, pp. 1355-1366, March 2012, doi: 10.1109/TIE.2011.2167729.

[5] J. M. Lazi, Z. Ibrahim, MHN Talib, A. Alias, A.Nur, and M. Azri, "Speed and position estimator of for sensorless PMSM drives using adaptive controller," International Journal of Power Electronics and Drive System(IJPEDS), vol. 10, no. 1, pp. 128-136, March 2019, doi: 10.11591/ijpeds.v10.i1

[6] M. A. M. Cheema and J. E. Fletcher, "Sensorless vector control of linear permanent magnet synchronous motor," 2013 IEEE ECCE Asia Downunder, 2013, pp. 1098-1104, doi: 10.1109/ECCE-Asia.2013.6579245.

[7] H. Aberkane, D. Sakri, and D. Rahem, "Improvement of Direct Torque Control Performances Using FCS-MPC and SVM Applied to PMSM: Study and Comparison," 2018 International Conference on Electrical Sciences and Technologies in Maghreb(CISTEM), 2018, pp. 1-6, doi: 10.1109/CISTEM.2018.8613340. 
[8] M. I. Ullah, S. A. Ajwad, M. Irfan, and J. Iqbal, "MPC and H-Infinity Based Feedback Control of Non-Linear Robotic Manipulator," 2016 International Conference on Frontiers of Information Technology (FIT), 2016, pp. 136-141, doi: 10.1109/FIT.2016.033.

[9] X. Sun, H. Yu, and X. Liu, "Design and Application of Sliding Mode Controller in PMSM Position Tracking Control Based on Adaptive Backstepping," 2018 Chinese Automation Congress (CAC), 2018, pp. 3507-3511, doi: 10.1109/CAC.2018.8623152.

[10] H. Echeikh, R. Trabelsi, H. Kesraoui, A. Iqbal, and M. F. Mimouni, "Torque ripples improvement of direct torque controlled fivephase induction motor drive using backstepping control," International Journal of Power Electronics and Drive System (IJPEDS), vol. 11, no. 1, March 2020, pp. 64-74, doi: 10.11591/ijpeds.v11.i1.

[11] K. N. Achari, D. V. A. Kumar, and M. V. Kumar, "Sensorless Control of IPMSM Drive using EKF with Electromagnetic Noise Effect," International Journal of Power Electronics and Drive System (IJPEDS), vol. 9, no. 1, March 2018, pp. 157-165, doi:10.11591/ijpeds.v9.i1.

[12] M. S. Termizi, J. M. Lazi, Z. Ibrahim, Md H. N. Talib, M. J. A. Aziz and S. M. Ayob, "Sensorless PMSM drives using Extended Kalman Filter (EKF)," 2017 IEEE Conference on Energy Conversion (CENCON), 2017, pp. 145-150, doi: 10.1109/CENCON.2017.8262474.

[13] L. Qi, T. Jia, and H. Shi, "A novel sliding mode observer for PMSM sensorless vector control," 2011 IEEE International Conference on Mechatronics and Automation, 2011, pp. 1646-1650, doi: 10.1109/ICMA.2011.598596.

[14] S. Aarathi and C. K. Vijayakumari, "FPGA based sliding mode control of PMSM for torque ripple reduction," 2017 IEEE International Conference on Power, Control, Signals and Instrumentation Engineering (ICPCSI), 2017, pp. 1088-1093, doi: 10.1109/ICPCSI.2017.8391878.

[15] B. Majout, D. Abrahmi, Y. Ihedrane, K. Mohammed, and B. Bossoufi, "Improvement of sliding mode power control applied to wind system based on doubly-fed induction generator," International Journal of Power Electronics and Drive System (IJPEDS), 2021, vol.12, no.1, pp. 441-452, doi: 10.11591/ijpeds.v12.i1.

[16] E. Paiva et al., "Sliding Mode Current Control with Luenberger Observer applied to a Three Phase Induction Motor," 2020 5th International Conference on Renewable Energies for Developing Countries (REDEC), 2020, pp. 1-5, doi: 10.1109/REDEC49234.2020.9163602.

[17] G. R. A and K. R. Santha, "Review of Sliding Mode Observers for Sensorless Control of Permanent Magnet Synchronous Motor Drives," International Journal of Power Electronics and Drive System (IJPEDS) vol. 9, no. 1, pp. 46-54, 2018, doi: 10.11591/ijpeds.v9.i1.pp46-54

[18] Y. Wu, Y. Fang, L. Liu, and Y. Zhang, "Global dynamic sliding mode control of PMSM speed servo systems base on extended state observer," Proceedings of the 32nd Chinese Control Conference, 2013, pp. 4432-4437.

[19] W. Xu, Y. Jiang, and C. Mu, "Novel Composite Sliding Mode Control for PMSM Drive System Based on Disturbance Observer," in IEEE Transactions on Applied Superconductivity, vol. 26, no. 7, pp. 1-5, Oct. 2016, Art no. 0612905, doi: 10.1109/TASC.2016.2611623.

[20] M. U. Salamci and G. S. Tombul, "Sliding mode control design with time-varying sliding surfaces for a class of nonlinear systems," 2006 IEEE Conference on Computer-Aided Control System Design, 2006 IEEE International Conference on Control Applications, 2006 IEEE International Symposium on Intelligent Control, pp. 996-1001, doi: 10.1109/CACSD-CCA-ISIC.2006.4776780.

[21] D. Bao, Y. Wang, X. Pan, X. Wang, and K. Li, "Improved sensorless control method combining SMO and MRAS for surface PMSM drives," 2017 IEEE Industry Applications Society Annual Meeting, 2017, pp. 1-5, doi: 10.1109/IAS.2017.8101744.

[22] X. Liu, H. Yu, J. Yu, and L. Zhao, "Combined Speed and Current Terminal Sliding Mode Control With Nonlinear Disturbance Observer for PMSM Drive," in IEEE Access, vol. 6, pp. 29594-29601, 2018, doi: 10.1109/ACCESS.2018.2840521.

[23] X. Guo, S. Huang, and Y. Peng, "Robust Speed Sliding Mode Control for PMSM Based on A Novel Reaching Law and High-Order Fast Terminal Sliding-Mode Observer," 2020 12th IEEE PES Asia-Pacific Power and Energy Engineering Conference (APPEEC), 2020, pp. 1-5, doi: 10.1109/APPEEC48164.2020.9220510.

[24] Y. Wang, K. Li, and X. Liu, "Improved Deadbeat Control for PMSM with Terminal Sliding Mode Observer," 2019 22nd International Conference on Electrical Machines and Systems (ICEMS), 2019, pp. 1-5, doi: 10.1109/ICEMS.2019.8922163.

[25] X. Zhang, L. Sun, K. Zhao, and L. Sun, "Nonlinear Speed Control for PMSM System Using Sliding-Mode Control and Disturbance Compensation Techniques," in IEEE Transactions on Power Electronics, vol. 28, no. 3, pp. 1358-1365, March 2013, doi: 10.1109/TPEL.2012.2206610.

[26] W. Xu, A. K. Junejo, Y. Liu, M. G. Hussien, and J. Zhu, "An Efficient Antidisturbance Sliding-Mode Speed Control Method for PMSM Drive Systems," in IEEE Transactions on Power Electronics, vol. 36, no. 6, pp. 6879-6891, June 2021, doi: 10.1109/TPEL.2020.3039474.

[27] F. C. Ogbuka et al,. "A robust high-speed sliding mode control of permanent magnet synchronous motor based on simplified hysteresis current comparison," International Journal of Power Electronics and Drive System (IJPEDS), Mar. 2021, vol.12, no.1, pp. 1-9, doi: 10.11591/ijpeds.v12.i1.

[28] K. Makhloufi, I. K. Bousserhane, and S. A. Zegnoun, "Adaptive fuzzy sliding mode controller design for PMLSM position control," International Journal of Power Electronics and Drive System (IJPEDS) Jun 2021, vol. 12, no. 2, pp. 674 684, doi: 10.11591/ijpeds.v12.i2.

[29] K. M. A. Prasad and U. Nair, "Intelligent fuzzy sliding mode controller based on FPGA for the speed control of a BLDC motor," International Journal of Power Electronics and Drive System (IJPEDS), vol. 11, no. 1, March 2020, pp. 477-486, doi: 10.11591/ijpeds.v11.i1.

[30] A. A. Mekki, A. Kansab, M. Matallah, Z. Boudjema, and M. Feliachi, "Super-twisting sliding mode controllers based on D-PSO optimization for temperature control of an induction cooking System," International Journal of Power Electronics and Drive System (IJPEDS), vol. 11, no. 2, June 2020, pp. 1055-1064, doi: 10.11591/ ijpeds.v11.i2. 


\section{BIOGRAPHIES OF AUTHORS}
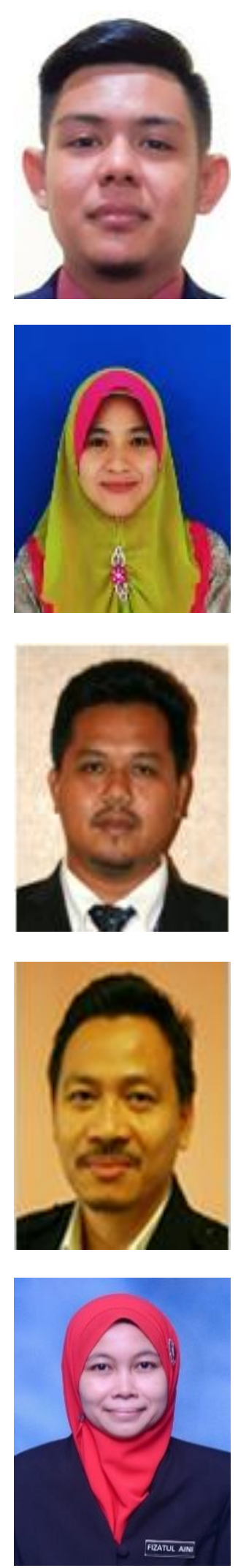

Muhammad Haziq Nashren Razali (iD 81 SC P received a bachelor's degree in electrical engineering (Majoring in Industrial Power) from Universiti Teknikal Malaysia Melaka in 2019. Now he is working as an electrical engineer in the private sector. His interest is in Power Electronic and AC Motor drives. He can be contacted at email: haziqnashren96@gmail.com. His social media LinkedIn: https://www.linkedin.com/in/haziq-nashren-814465190.

Jurifa binti Mat Lazi (D) SC P received her Bachelor's degree in Electrical Engineering from Universiti Teknologi Malaysia in 2001. She then obtained her Master of Science degree in Electrical Power Engineering from University Universiti Teknologi Malaysia, in 2003. She received her Ph.D degree from University Universiti Teknikal Malaysia Melaka in 2016. She has served as an academic staff at Universiti Teknikal Malaysia Melaka (UTeM) since 2001 and she is currently a senior lecturer. Her research interests include Machine Drives especially in Sensorless and PMSM drives, Power Electronics and Power Systems. She can be contacted at email: jurifa@utem.edu.my.

Md Hairul Nizam Talib (D) 8. SC P was born in Malaysia, in 1976. He received his B.S. in Electrical Engineering from the Universiti Teknologi Malaysia (UTM), Johor, Malaysia, in 1999, M.S. in Electrical Engineering from the University of Nottingham, Nottingham, UK, in 2005 and PhD from the Universiti Teknikal Malaysia Melaka (UTeM), Malaysia in 2016. $\mathrm{He}$ is currently a senior lecturer at UTeM. His main research interests include power electronics, fuzzy logic control and motor drives. He can be contacted at email: hairulnizam@utem.edu.my.

Zulkifilie Ibrahim (iD) 8 SC P was born in 1966 in Malaysia. He received his B.Eng. degree from the University of Technology (UTM), Malaysia in 1989 and his $\mathrm{PhD}$ degree from the Liverpool John Moores University, UK in 1999. He is currently a Professor at Universiti Teknikal Malaysia Melaka (UTeM), Malaysia. His main research interests are related to Power Electronics, fuzzy logic control, embedded system design and electric motor drives. He can be contacted at email: drzulkifilie@utem.edu.my.

Fizatul Aini Patakor (D) SC P was born in Malaysia, in 1978. She received her bachelor's degree in Electrical Engineering (Power Electrical) from the Universiti Sains Malaysia (USM), Malaysia, in 2001, Master of Science in Occupational Safety and Health from the Universiti Utara Malaysia (UUM), in 2008, and PhD in Electrical Engineering from the Universiti Teknikal Malaysia Melaka (UTeM), Malaysia, in 2014. She is currently a Senior Lecturer at Politeknik Merlimau Melaka (PMM), Malaysia and her interest includes safety and health in engineering education, power electronic and drives control systems. She can be contacted at email: fizatul@pmm.edu.my. 